\title{
Memories of Childhood in Post-War Grimsby
}

\author{
JOHN A. SMITH \\ Department of Education and Community Studies, University of Greenwich, UK
}

This paper details the vivid memories of the author's childhood in the fishing port of Grimsby, shortly after the Second World War. It was a time of shortages, overcrowding, improvisation and cannibalisation of anything that could be re-used. In time it became a period of reconstruction but not without its upheavals and difficulties. It begins in the 'old town' of workers' small terrace houses, typically in a poor state of repair. Then it moves to the 'new' council estates. Similarly, the narrative also begins with a 'Victorian 'technology of steam, coal and horses with very few petrol-engined vehicles and moves to the very beginnings of early consumer society. The principal analytic content of the paper concerns the status of what is clearly a 'personal history' - if that is not too great a contradiction - or as the author suggests: my story. The obvious 'critical' response - that it could have been otherwise - is contrasted against the suggestion that this story is a nonnegotiable foundation of the author's identity and that this 'critical' response is not appropriate. Some of the interdisciplinary options thrown up by this problem are considered.

Keywords: agonic solidarity, cognitive biology, complexity theory, my story, path dependency, constrained possibility

\section{Introduction}

I am not a historian. I do not propose to become an amateur one now. You will find little historical support for my memoir. I am the entire source. In part two I shall bring to bear my disciplines - sociology, socio-biology, philosophy, cognitive biology and complexity theory - on my (his)story. I was born in April 1947 into an Edwardian Age: horse-drawn, steam-powered, coal-fired; hardly a petrol engine in sight. There was a light fawn VW Beetle round the corner in Eleanor Street. It was left hand drive and never moved. Everyone assumed it had somehow been got back here from Germany but we never knew. The only evidence of petrol power was a garage at the end of the street which limped on, barely busy, usually converting, cannibalising ex-military vehicles for civilian use. But it did have a Morgan three-wheeler 'sports' car powered by a Brough Superior V-twin 1,000 cc. motorcycle engine, mounted on the front. It occasionally fired up loudly and drove around the square. That, the old damaged houses and the fishing trade was my infant world.

I was born in Grimsby and lived in Roberts Street in my grandmother's house with my mother and father, grandmother and aunt. It was, and still is, a harsh town, physically and culturally, harshly spoken, grimly pragmatic, and isolated. It was, but no longer is, a thriving fishing port. My grandfather had been a fisherman who was lost at sea during WW2. The War also dominated the fabric of the house: bomb damage surrounded the street, causing subsidence, cracking, hurried temporary repairs that unconvincingly persisted, doors that no longer closed, wedges to get the furniture level. But above all, stood the inescapable fact of overcrowding. The housing shortage was such that families and generations were forced to multi-occupy houses that were painfully small Victorian terraces in the first place. Their condition was such that roofs leaked, ceilings drooped, floor angles were ridiculous. They were also infested with large black beetles - we called them blackclocks cockroaches and rats: the latter rarely seen inside but commonplace outside. They were under every shed, outhouse, and remaining airraid shelters. Compared to others, though, we were not so badly housed. My grandmother owned the house - bought through 'compensation' for a pair of husbands, one lost in each war. My earliest memories concern a black and white pram. The make was, I recall:

Tan Sad. No, I could not read as a baby. It was still in use five years later when my sister was born. The first was at Hainton Square. I was in the pram but so was a tortoise. As it crawled around my legs I felt a mixture of fascination and revulsion - the latter sharpened by the constant fear of beetles, a phobia I still have. Fascination won. Cleo, as he came to be known, was altogether nicer than a blackclock. I touched his shell and his head and legs retracted. I found that enormously funny then and for the many years he lived with us. He buried himself each winter and emerged in the Spring. Eventually he did not reappear. The second was in that same pram, this time around the corner in Weelsby Street. I cannot recall who was pushing but they were playing that game of pushing the pram hard, then running to catch it. That happened several times in the 100 yards or so to Roberts 
Street. It was a game I loved. My next memories relate to incidents when, I think, I must have been three or four. I was walking with my grandmother in Wellington Street, close to Roberts Street, on the way to Freeman Street to collect her pension. Just off Wellington Street was Snowden's Sawmill. It was a key centre for reconstruction. The logs were imported from Sweden and hauled from the docks on long carts pulled by shire horses. The sound of their hooves was lovely but commonplace but this time it was different - accompanied by a strange, consistent hiss. This turned out to be cannibalised aircraft tyres, fitted to the cart. On reflection, I think the whole wheels had been cannibalised but all I recall was the amazement at this combination heading down a familiar street. Next I turn to the docks themselves. My father had a very, very rare day off. We went to see my grandfather at work. We got there by bike - I had a child's seat bolted to the crossbar. I remember my shock, and pleasure, at how close the railway and the pathways were. They actually intersected. You had to look right and left, not for cars but for the saddle-tank shunting engines and their wagons. You could easily touch them. It was entirely accepted that something so heavy could not easily stop. The risk was entirely yours. The contribution to this lottery from the engine drivers was punctuated whistling. The sight, the smell, and the wetness of fish was everywhere. They were so remarkable in shape, colours, sizes. And everything containing or carrying fish relentlessly leaked water from melting ice. The occasional discarded dogfish prompted claims that it was actually a shark; certainly an impressive predator. I declined my father's invitation to walk round the trawlers. Yes, that was possible.

They were surrounded by so-called floating pontoons - in other words stout timber rafts tethered to the ships. But the swell, even in the closed dock, was intimidating. When vessels moved or the dock-gates opened, it was terrifying, though skilled pontoon walkers carried on regardless. I was disinclined to get as close to the ships as I did to the engines. But this was not the singular spectacle. My paternal grandfather was a boilermaker. This was a skilled and responsible craft. A fault in a powerful boiler could result in a serious explosion. On a steamship - and all the ships were steamships - the likelihood would be sinking. This did not stop him living in grinding poverty. His workplace was a dockside building. We heard it from afar and the noise grew. Eventually we saw him through open doors wide enough to accommodate large vehicles. He was pounding a plate of red hot steel, held in two sets of enormous tongs. Or rather, he wasn't doing the pounding. He was feeding the steel plate to an immense steam hammer at least four metres high, which visibly reduced the plate's thickness with every strike. The process was akin to rolling except that the percussion was so extreme that the building shook and you could not hear anything. The entire apparatus exceeded the threshold of hearing. My grandfather, not wearing any kind of ear protection, though he did have a thick leather apron, continued to manipulate and reposition the plate until he was satisfied. The hammer ceased. Something like hearing slowly returned and my grandfather disappeared in a cloud of steam as the plate was doused. Then he reappeared and smiled. 'Elor' he said in his rural Lincolnshire accent. I was speechless. The house in Roberts Street was arranged three rooms deep and two stories high. The front door opened onto the street. There was a boot scraper to the left of the front door and the step was 'stepstoned' that is, cleaned, every Monday. The same happened in every other house. The front room was kept for ultra-special occasions though I did wander in from time to time, to sample the silence and strange atmosphere. It was so packed with furniture that even I as a child had to squeeze in. For some obscure reason that I can no longer recall I decided that a wolf might live there. So my visits were short. This room was most affected by subsidence and had the most improbable floor angle. Every piece of furniture was wedged in some way, usually with wood (my father was a joiner) but also finely adjusted with empty, flattened, folded cigarette packets. Next came an understairs cupboard: the stairs were at right angles to the house so that you were actually entering the wider part and the shallowest part was also the deepest. Now I was fascinated by cupboards and drawers. Amidst the tangles of cotton and wool there were old coins, silver sixpences, farthings with wrens on them, Victorian pennies, bits of old tools, pictures, cutlery, even discarded cheap jewellery. But in this particular cupboard, I knew, there were blackclocks, lots of them, the deeper you went. If you disturbed them, they would run around frantically chaotic paths, like flies do when they are threatened. Unfortunately it tended to produce a similar reaction in me. Next came the living room. In the far right corner was a window but this and the next door house formed an effective 'canyon' two stories high so that even on a bright day the light was awful. One 40 watt bulb compensated. On the right wall was a fireplacerange; the fire on the left and an oven on the right. There was often a kettle on the fire. This too was treated with caution, especially in the morning. Cockroaches like warmth. The door to the staircase was in the near right corner. The room was again crammed but not so badly as the front room with a dining table, a settee, two armchairs and a sideboard. There was a small table by the window that supported an object of immense fascination: the radio. I loved the Home Service. Listen with Mother, Mrs. Dale's Diary, and the Archers were special treats. Next came the kitchen. It had one small window and so was permanently dark, except for the light bulb. There was a stone sink with a cold water tap, a gas stove, and a pantry. Outside was a lavatory, a coal 
house and a small garden. A large industrial building lay beyond the garden and access passage. I cannot recall its function. There were three bedrooms upstairs but, of course, no bathroom. I had wooden toys. My father made a red, wooden tank engine. Turned over it also served as a see-saw. Whilst he was a woodworker, making toys for children was not unusual. I recall books showing how to make forts, doll's houses and the like. All relentlessly sexist of course. My wife still has a doll's house that her father, then a schoolteacher, made from these books. A dolly tub doubled as a boat. Two chairs, back to back, roofed with a tea tray and supplied inside with a circular tray became a bus. All sorts of uses were made of soap bubbles, bolts and explosive caps, tin cans, and cloth parachutes. In time I began to be given and collect 'Dinky' toys. By that time things were getting better. The street play culture was an altogether different matter. At the 'Rialto' end of the street the children played in the road and gutters. It was a dead end, culminating in a foot passage so no traffic went there. It was the dirty end of the street. Many children were without shoes or underclothes. Dog excrement was a significant element of risk and status games. At the other end was a park. That was where the respectable families lived. We were stuck halfway. I didn't spend much time in the street, preferring the garden but if you had playmates there was no way of evading 'dogdirt' altogether. It was particularly unpleasant in the hair or as substitute marbles.

My Aunt Glad (Gladys) Williams lived on Roberts Street too but actually even past the park where the even more respectable people lived. She had a magnificent Edwardian house with square bay windows. There was no garden though, just a garage and stabling. Uncle Williams - I think his actual name was George - was a general haulier. Horses and carts of course. They did actually own a car; a pre-war Vauxhall, coach built and looking exactly like a coach. It had red buttoned leather seats, brass metalwork, and the characteristic chrome bonnet insets that were the Vauxhall trademark. I only saw it once actually running.

Aunt Glad and Aunt Madge were sisters. Aunt Iris, who lived with us and Gran had been 'in service' with the family until War broke out and remained on friendly terms. Madge too had an impressive Victorian house, three stories high in a terrace in Eleanor Street. This was just as respectable but had also been affected by bombinginduced subsidence. The floors were flat but the roofline was distinctly curved.Madge was married to Uncle Billy Twyman - who I never saw. He was one of the many claimed by tuberculosis and was in the 'isolation hospital'. He had a shop in Freeman Street - part sporting: fishing rod and the likes; and part toys - but of very high quality. They were things like electric trains and model Mercedes cars with folding roofs. They were variously named as 'German Toys' or 'Uncle Billy's Toys'. Either way they indicated a recovery in German manufacturing, especially high quality manufacture by the early fifties. That was hard to discern in Grimsby but as I said, it was an isolated harsh town with a hardly visible middle class. Glad and Madge were exceptions but my great grandmother Maria had also been a businesswoman. My sister was born in November 1951 and so we 'qualified' for rehousing. In the summer of 1952 we moved to the New Nunsthorpe Council Estate. Now notorious, it was then the great dream of my parents who were fully paid up members of faith in the new Welfare State - just like every workingclass family in the town. Our first visit was striking. Only the basics were there. No metalled roads or pavements though there was a bus service through 'Old' Nunsthorpe to the edge of 'New'. Our house was a three bedroom terrace and literally the edge of town. Behind it lay farmland. The issue of social rank was as obvious here as in Roberts Street. There were good roads and bad. Everyone could tell one from the other and all the shades in between. Ours, then, was a good street. Likewise there were good, bad and in between estates. The Grange estate was bad. The Weelsby estate was good. Nunsthorpe was 'mixed'. After a few weeks, a fleet of trucks arrived and dumped topsoil for the gardens. Since there were no fences, since Frank next door 'knew his onions', since rationing was still in force, the gardens immediately become a joint smallholding and remained that way for several years. The schools were equally improvised. I say 'schools' but there was in fact only one site in Old Nunsthorpe. This site accommodated - if that is the right word - a nursery, a mixed infants, a boys' junior school, a girls' junior school, both fourform entry, and a secondary boys' school that eventually moved away to make room for the boys' and girls' junior expansion. There was a mix of the original school buildings and many, many prefab classrooms. To give you some idea of the total population, the junior school class size was around forty. For the first day, or the first week if you were lucky, parents or older siblings took you to school. After that you were on your own. Unthinkable nowadays, this meant typically a half mile walk where the adverse risks were the weather, other kids, stray dogs, by then increasing traffic and your being far too young. I remember little about the infant's school except separation anxiety, getting over that, the intriguing presence of girls of my own age and then the gradual discovery that I was quite able. The full scale and bleakness of school did not hit me until what would now be called year three: first year junior. Here we were immediately streamed, A to D. I was in the A class. A boy called Peter who lived next door but one was in the D class. They didn't realise till years later that his problem was glue ear. In the fearful terminology of those days, he was considered 'backward'. On 
the first chilly September day of junior school, three things were immediately apparent: poverty, brutality, and disease.

Poverty was easy to see. The boys on welfare - then called national assistance - wore brown corduroy bomber jackets and shorts, hob-nailed boots, and short haircuts. I don't know whether there was a female equivalent. Corporal punishment, or rather its scale, became more apparent as we got older. The same people seemed to be beaten regularly. It was often difficult to see why, but I was careful to avoid trouble. The mood was constantly hostile between staff and pupils and very often between pupils. Those in lower streams were openly despised. I was not innocent of this but then one had to exploit every competitive advantage one had. Tenhouten (2007) calls this form of social organisation 'agonic'. How apt! He adds that those at the bottom of the hierarchy do not even have sovereignty over their own bodies. The evidence for this was ample. However, your position in the hierarchy, as a child, was always dangerously ambiguous. This was a society marked by constant fear. And also by the typically masculine social need to conceal it. Everyone was terrified by Polio Myelitis. Several survivors were at the school with varying degrees of paralysis, supported by leg irons. Each summer, outbreaks, not necessarily local, fuelled the fear and sites such as swimming pools were closed. By contrast the most destructive and disruptive were the ubiquitous childhood diseases: scarlet fever, rubella, mumps, chicken pox, but especially measles, usually followed by whooping cough. That combination radically changed my childhood. I contracted measles at the age of seven. My sister, aged three, inevitably caught it too. I don't remember much about measles, except that it took at least a month of fatigue and sleep to abate. I fully remember whooping cough. It was a known post-measles complication and every family hoped it would not follow because it would turn a serious and unpleasant condition into a persistent and debilitating one. My sister also caught it. Even when the symptoms became less severe, we could not go out because of that all too recognisable cough. People disapproved strongly. My father's answer was to take us out early to a wood not too far way and let us cough at least in some fresh air. As soon as anyone else arrived, we had to go home. That episode cost me several months of missed schooling but I dealt with that easily enough. There was a further legacy: severe asthma. After whooping cough, any kind of physical exertion produced an asthma attack. Run a few yards for a bus, suffer an hour's acute wheezing and coughing. I became 'a sickly child'. Treatments - in my case ephedrine - were ineffective and produced depressive side effects. School sport was a nightmare: I was invited to 'try' with obvious consequences. One or two teachers recognised that trying was not appropriate but this 'acquired' medical disability had profound discriminatory social effects in the 'educational' setting.

A particularly devastating aspect was a sudden, grossly severe attack with no apparent cause. I remember my tearful mother and white-faced father collecting me in the middle of such an attack from an attempted holiday with my grandmother in a seaside caravan. They suspected the worse: could this be polio? Our doctor, a sympathetic man was called out but by that time I was absolutely fine. He questioned my mother closely as she described the condition she found me in. He was puzzled but accepted that this was an issue he did not understand. A specialist was consulted. His ambiguous reply was: 'If I didn't know better I'd call you a phoney'. One furious but determined child left the hospital. Specialist? If anyone was the specialist, it was me. Eventually I tracked down the cause. I had become extremely allergic to the 'Utility Brand' grey wool blanket. They were in most houses and even slight proximity triggered severe asthma attacks. There were some in our house but my mother had replaced them with something easier to wash and dry. Allergy was not then really understood but I knew it well. Much later, tests proved me right. Time to pause. What is the status of this recollection? It may be seen as a form of creative non-fiction or even ethnographic fiction (Bignold, 2011). This equivocation underlines that what for 'an other' is creative or fictional, but for the teller carries a level of necessity, a personal imperative I propose to deal with that complexity in two sections. The first I shall address here: the centrality of imagination to human conceptualisation. The second will follow after a further narrative memoire on the attribution of cause and the shape or 'landscape' of possibility. Neither of these are strictly historical or philosophical but are related to these disciplines with differences derived from the theory of the emergence of complex order (Kauffman,

1993, 2008; Prigogine, 1996), which, I ; shall argue, can be seen to identify history with ontology - without avoiding the epistemological problems that follow. I have criticised Kant's Critique of Pure Reason elsewhere (Smith and Jenks, 2006). But the core of his philosophy remains central to my work and the following persists in the modern form of metaphysics: In that truth becomes certainty and thus beingness (ouisia) of beings changes to the objectivity of the perception and the cogitato of consciousness ... knowing and knowledge move into the foreground ... Epistemology is the tile for the increasing, essential powerlessness of modern metaphysics to know its own essence. (Heidegger, 1973: 88-9) To claim that Kant's notion of 'synthesis' or construction is central to modern epistemology in its sociological or philosophical forms is hardly controversial. To acknowledge the centrality of 
This is an Accepted Manuscript of an article published by Taylor \& Francis in Childhood in the Past: An International Journal on 24 Oct. 2014, available

online: http://www.tandfonline.com/doi/full/10.1179/1758571614Z.00000000019

something very similar - structural coupling (Maturana and Varela, 1980) - to cognitive biology, however, throws up many new issues. Perhaps, as we shall see, this is better understood as the philosophy of cognitive biology and contests what we might mean by philosophy: the philosophy of history in particular. As a preliminary, I want to argue that history is not best understood as something done by historians. From a 'democratic' perspective we are all historians. From a complexity perspective everything is path-dependent and this path, or history, is an active agent in the real landscape as opposed to the formal dimensions of present/new possibility. In Critique of Pure Reason (1975), Kant speaks of three syntheses: of the past, the present, and the future. By 'synthesis' he clearly intends re-presentation in or by human imagination (see Smith and Jenks, 2001, 2006). Whether we like it or not, this implies that space and time and the representation of objects within those fields are re-presentations, acts of re-membering, or modelling. Put differently human conceptualisation is imaginative representation in space and time. The modern identification of space-time is not especially relevant here since we are speaking of 'classical' dimensions of speed and energy. What is crucial, however, is the parallel between Kant's syntheses and cognitive biology.

For me the best source, and certainly the most beautifully written is Maturana and Varela (1980) - a founding text for cognitive biology, cybernetics, posthumanist epistemology, semiotics, hardly known in sociology or philosophy. The key term is 'autopoiesis' - the self-structuring of living organisms. Not only do they structure themselves in the physical sense but they determine the form of structural coupling to the environment. Put radically: 'The organism decides what counts as environment.' Maturana and Varela characterise structural coupling at the same time as operational closure: '[Any] perceptual system does not so much register reality as

construct it' (Smith and Jenks, 2006: 48, Hayles, 1999: 135). < Let us consider the difference in project between the philosophical and the cognitive-biological concepts of synthesis. Kant's concern is certainty (Heidegger, 1973: 88-9) whereas the primary concern of biology (and its organisms) is the sufficiency of perceptual syntheses for survival (Smith and Jenks, 2006: Ch. 8; Varela et al., 1997). My memories may reflect my beliefs,

may be plausible for the $=$ reader, but are by no means certain or even certifiable. My mother and I differ in some of the details. I have reworked these memories consciously and unconsciously throughout my life. They are not simply 'past' but a central part of my 'present'. I have no idea why these particular memories 'stick' when others don't. I certainly cannot claim to be representative. And yet I experience them as necessary in the sense of being an essential part of my coherence and identity. Perhaps this comment is apt: 'In practice the issue of learning becomes a question of what can penetrate the individual, semi-automatic defence mechanisms and under what conditions' (Illeris, 2006: 95-6).

To conclude this section then, I am suggesting that the imaginative construction of identity is absolutely central to human being. It cannot be forgone for the sake of 'reason', which would leave us with formal certainty but without substantive, concrete, questionable content. Put differently, the coherence of the narrative may be at least as important as its certainty or truth. Sociology and philosophy tend to regard this substantive content as 'socially constructed' or conventional or contingent in the strict sense of 'could have been otherwise'. Of course I must agree: reason demands that this is formally true in all cases. Then I must also respond that the formally true in all cases stands in direct opposition to the requirement of a specific identity, however fluid we may consider that to be. This amounts to the suggestion that there are two forms of the necessarily true: formal axioms set against those specific truths that are necessary to identity or survival. We could, and should, for reason's sake, say that the latter are necessary or true to a degree. But that means they cannot be formally discussed, or better, dismissed as conventional. Nor can they be regarded safely as a unified category of 'experience'. That is formalism by the back door. And there is no a priori ground for the collection of these diverse perceptions as necessarily similar. That is simply an unreasonable habit, a misplaced formalism, an idiom that philosophy and sociology habitually use. Put radically, identity and conventionality are fundamentally opposed principles. The latter threatens and potentially destroys the former.

This point is crucial so I shall rework it in another way. We concede that animals construct a world that is objective to their species. Following Sebeok and Deely (2002) I shall call this their Umwelt. We do not regard this as

subjective in the $>$ sense of 'could have been otherwise' but rather as the character of that species' adaptation and central to survival. Objective and subjective take on far more subtle nuances here than in the blunt oppositional sense normally applied to human perceptions by certain disciplines. Indeed, the principal criticism of an abbreviated version of this paper at a recent conference was that I did not concede that my-story could have been otherwise, could have been interpreted differently. 
The criticism came from a physicist and a historian. It could just as easily come from sociology or philosophy. My contention is that this criticism, or better, the question of the alternative, is not inevitable nor necessarily the most important critical dimension. My priority is not the alternative(s) but the salience of the images I chose. If you concede that is reasonable on my part, that the question of alternative(s) is not inevitably the most important dimension, then to insist on the contrary as absolute does not describe the limits of reason but the habits of an idiom. In short, it is normative rather than necessary. Or better: that conditioned reflex routinely passes for critical reasoning. I will not, then, concede that the articulation and interpretation of alternatives is a reasonable imperative. Citing the far more intelligent (in my view) idioms of fuzzy logic (Kosko, 1994) I will only concede that alternatives are only possible or relevant to a degree. I maintain that position whilst at the same time acknowledging not only imaginative construction but far more importantly the deliberate omission of absolute certainties (to me) that are far too sensitive to reveal. That is the essential difference between history and my-story. I am not a formal individual who could have been otherwise without limit.

Back to the narrative. At the age of ten I was taken to London by my cousin Brenda. Yes, she could have had a different name. So could her then boyfriend, Noel. Or we could have not gone there at all. Yes I acknowledge these formal possibilities but that is not the point. The real issues are somewhat more interesting and questionable. My first sight of London was King's Cross and in particular a Gresley A4 class locomotive (like Mallard). This confirmed to me that contrary to the protestations of John Lingard - a schoolmate who picked the warts on his thumb - that such things did actually exist. They were not simply representations in books. Much the same applies to my first experience of the shattering noise and dust of the London Underground.

These could have been but were not the main experience. The key was a visit to the British Museum. The first gallery I visited (or remember) was the ground floor collection of Egyptian statuary. For those not familiar with the exhibits, they vary in size from enormously monumental, to life size, to miniature representations.

What they had in common for me, now and then, was a high degree of formal finishing, together with an enormous visual inventiveness and, characteristically, often carrying hieroglyphic text, which (then and now) I could not decipher. But I could certainly recognise the difference between text-less pictorial traditions and amazing juxtapositions of half-animal, half-human forms. The confirmation of their reality rather than illustration was also awesome. We climbed the stairs decorated by Roman mosaics to the upper Egyptian galleries. Again, for those unfamiliar with the collection, these areas are dominated by mummification, grave goods, small objects, even toys. Partly by degradation, partly by intent, the character of representation was breathtakingly different. These objects were crude, primitive, and yet so evocative as objects. I loved them every bit as much but completely differently from those downstairs. A model boat with sails and oarsman - grave goods, not toys - both connoted the wooden toys of my childhood with simple wooden figures and yet announced an unbridgeable difference. Similarly, the mummification - I was less interested in the humans than the mummified cats, snakes, falcons and the like - invoked an understanding of how they were made but also announced their age and complete cultural difference (or so I thought at the time). To reiterate: the shock, the interest, the fascination was the differences in representation both between the galleries and between my world and that of the ancients. I could not speak. There was and to a great extent still is, no way to articulate this in speech. The impressions I strive to convey here are minimal. It was not until I went to art school, much later and arguably by accident, that these questions of the manner and techniques of representation and the fascination with objects struck me, that such things could be engaged with through drawing and painting. Then I began to feel the enormous continuity between the ancient and the modern, through art, through the human impulse to make images and designs: the claim, even imperative, of homo aestheticus (Dissanayake, 1992). I must now stretch the boundary of childhood to include my first experiences at art school, aged sixteen to twenty-two. The first shock in confronting painting and drawing seriously was that the questions I raised about representing, image making, design, colour were not just personal, the way I had experienced them at the Museum, but part of a public discipline that was open in principle, so long as you committed to the practice of art. I say 'practice' and 'discipline' rather than 'discourse' or 'history' because I remain intolerant of the type of analysis that regards objects of art as cyphers to be dis-encrypted by reference to social contexts and literary explanations. I share the same intolerance that Cezanne expresses: distrust the literary spirit (Danchev, 2013). I warm to ' $m y^{\prime}$ intolerance rather than that which sees the visual artwork as a sign to be surpassed, used up, once the meaning, in words, is discovered (for a fuller discussion see loC). I hesitate to regard that museum visit as cause but certainly as an influence that opened the disciplines of visual practice. That public space must include both speaking and making. Making has its own dangers. The confusion of essence and appearance and its sociopolitical consequences are well-aired in Plato's Republic (see Smith and Jenks, 2000). They are powerfully developed in the Christian-Neoplatonism of Renaissance art theory, especially in Florence (Summers, 1981). For 
my part, I think artists rarely confuse the real and the image: Prometheus remains marginal and literary. Speakers are in more grave danger: they habitually mistake their naming for reality. In particular, they mistake or gloss the intrinsic formalism of verbal language, as I discussed above: I am not a formal immediate individual but a mediate member. The considerations that apply to the former - unlimited alteraity - do not necessarily apply to the bounded plasticity of the latter. At the time I was at art school there was a systematic and dominant error of this kind called Modernism. It mistook the category 'painting' for the variety of disciplines and practices it made possible. And it did so as though that were entirely natural: that conditioned reflex again passing for critical reasoning. Greenberg writes:I identify Modernism with the intensification, almost exacerbation of this selfcriticaltendency that Began with the philosopher Kant ... Cezanne sacrificed verisimilitude orcorrectness in order to fit drawing and design more explicitly to the rectangular shape of the canvas ... It was however the ineluctable flatness of the support that remainedfundamental ... Flatness, two dimensionality was the only condition shared with noother art and so Modernist painting oriented itself to flatness as it did to nothing else. (Greenberg, 1986, cited in Smith and Jenks, 2000: 1625) Notice the relation to Kant and the misplaced attempt to identify what is essentialto (Modernist) painting, namely its physical construction. Why should this be more important than the variety of practices, disciplines, preoccupations? Becausethese fundamentals are objective rather than subjective? Because they least yield to the postulate: could have been otherwise? So what are we left with? A dictionary definition of a common noun. What kind of essence is this? A simplistic reduction.

What is lost? Everything. It is a short walk from here to the last paintings, it was thought. Then postmodernism came to the rescue. Now nobody gives a damn about what painting really, essentially is. Metanarratives are to be disbelieved (Lyotard, 1984). Differently put, painting (and much else) has no essence. How do we deal with such an inessential phenomenon? I want to argue that my-story is an equally inessential phenomenon and yet is vital to me. I argue further that to place that reflex 'criticism' - (I) could have been otherwise - is to privilege the common noun 'person' over my proper name. This is not a route to a more critical history but merely a substitution of a formal subject for a proper one (in both senses). This is the challenge that faces a postmodern philosophy or more simply a postmodern conception of history: how do we deal with the vital but inessential?

\section{Conclusion}

I propose an assimilation from complexity theory. The imperative that I consider alternatives to my story without reserve stems from not Kant but a misreading. Kant writes in Critique of Pure Reason (1975, Book 3): 'Experience teaches us that a thing is so but not that it cannot be otherwise'. This may be taken as basic axiom of critical phenomenology. The problem is that it was intended to distinguish the essential and therefore a priori from mundane knowledge. The former is taken as the condition of the latter. It may in turn be said to stand as a modernisation of the Platonic distinction between essence and appearance. But in neither the Platonic nor the Kantian case does that rescue appearances from the status of the contingent or inessential. Each and every 'critical' insistence on reflex altereity - could have been otherwise - is simply a confirmation of that status as the crucial dimension. Hence Socrates' indifference to the mundane, hence the hemlock. Kierkegaard (1965) calls this the standpoint of irony. I want to argue that irony is not a proper nor critical response to the mundane, to the ordinary narrative. It is a dismissal. Complexity theory does not deal in this polarity between the essential and the inessential but rather deals with patterns of persistence and emergence. Evolutionary and ecological theories (see Smith and Jenks, 2006, especially chapters 1, 8, and 9) exhibit a similar conceptual framework. That which is robust in evolution, that which persists in ecology is not 'essential' in the Kantian sense but is simply capable of persisting, or 'viable' (e.g. Maynard Smith, 1982). Such persistence is both emergent and evident and this is sufficient to be 'memorable', to claim attention, to be taken seriously. A key but counter-intuitive term is determinate chaos (see Prigogine and Stengers, 1996). Water, for example displays 'chaotic' phenomena but these are determined by the properties of water and the environment it encounters. The chaos is limited or in the jargon 'attracted' around certain parameters. It is not easily predicted but nor is it wholly unpredictable. Historical analysis, I suggest would be better conducted under these auspices of attractors and determinate chaos rather than the philosophical sense of absolute contingency. Differently put, the proper space of the humanities is not the distinction between the essential and the inessential but a landscape of possibility that is determined by bounded ecological possibility. In fact, the concept potentially most central to the historical enterprise - one hidden its aspirations but hardly mentioned is central to complexity theory: path dependency (see Kauffman, 1993; Prigogine, 1996; Smith and Jenks, 2006). Differently put, the landscape of possibility is not entirely limited by but in a deep sense influenced by the place in which we find ourselves. Hence my-story, hence the vitality of identity, hence the close identity of historiography and ontology. Nothing is lost by daring to consider the emergent, the finite, the half-essential except the more questionable idioms of philosophical usage, still uninformed by the contemporary process sciences. 
This is an Accepted Manuscript of an article published by Taylor \& Francis in Childhood in the Past: An International Journal on 24 Oct. 2014, available

online: http://www.tandfonline.com/doi/full/10.1179/1758571614Z.00000000019

\section{References}

Bignold, W. 2011. Creative non-fiction: one approach to narrative research in education Educational Futures 4(1), 19-27.

Danchev, A. 2013. The Letters of Paul Cezanne. London: Thames \& Hudson.

Deely, J. 2002. The quasi error of the external world: an essay for Thomas Sebeok, in memoriam. Cybernetics and Human Knowing 10(1), 25-46.

Dissanayake, E. 1992. Homo Aestheticus. New York: Free Press.

Greenberg, C. 1986. The Collected Essays and Criticism, Clement Greenberg. Edited by J. O'Brian. Chicago, IL and London: Chicago University Press.

Hayles, N.K. 1999. How We Became Postmodern. London and Chicago, IL: University of Chicago Press.

Heidegger, M. 1973. The End of Philosophy. London: Souvenir Press.

Illeris, K. 2006. A comprehensive understanding of human learning, pp. 87-100, in Jarvis, P. and Parker, S.

(eds.), Human Learning: An Holistic Approach. Abingdon: Routledge.

Kant, E. 1975. Critique of Pure Reason. Translated by N. Kempt-Smith, 1781. London: Macmillan.

Kauffman, S. 1993. The Origins of Order: Self-Organisation and Selection in Evolution. Oxford: Oxford University Press, Technical Monograph.

Kauffman, S. 2008. Reinventing the Sacred: A New View of Science, Reason and Religion. New York: Basic Books.

Kosko, B. 1994. Fuzzy Thinking. London: HarperCollins.

Kierkegaard, S. 1965. The Concept of Irony. Bloomington \& London: Indiana University Press.

Lyotard, J.F. 1984. The Postmodern Condition: A Report on Knowledge. Translated from French by G.

Bennington and B. Massumi. Minneapolis: University of Minnesota Press.

Maturana, H.R. and Varela, F.J. 1980. Autopoiesis and Cognition: The Realization of the Living. Dordrecht and Boston: D. Reidel Publications.

Maynard Smith, J. 1982. Evolution Now: A Century After Darwin. San Francisco, CA: Freeman Press.

Prigogine, I. and Stengers, I. 1996. The End of Certainty: Time, Chaos and the New Laws of Nature. New

York: The Free Press.

Smith, J. and Jenks, C. 2001. Images of Community. Aldershot: Ashgate.

Smith, J. and Jenks, C. 2006. Qualitative Complexity: Ecology, Cognitive Processes and the Re-emergence of

Structures in Post-humanist Social Theory. London: Routledge.

Summers, D. 1981. Michelangelo and the Language of Art. Princeton, NJ: Princeton University Press.

Tenhouten, W. 2007. A General Theory of Emotions and Social Life. London and New York: Routledge.

Varela, F., Thompson, E. and Rosch, E. 1993. The Embodied Mind. Cambridge, MA and London: MIT Press.

\section{Notes on contributor}

John A. Smith, Department of Education and Community Studies, Faculty of Education and Health, University of Greenwich, Avery Hill Campus, Mansion Site, Bexley Road, London SE9 2PQ, UK. Email: sj50@gre.ac.uk 